\title{
Advantages of Grain Legume-Cereal Intercropping in Sustainable Agriculture
}

\author{
Aybegün Ton ${ }^{1, a, *}$ \\ ${ }^{1}$ Department of Field Crops, Faculty of Agriculture, Çukurova University, 01330 Adana, Turkey.
} *Corresponding author

A R T I C L E IN F O A B S T R A C T

Review Article Sustainable agriculture bases on certain ecological principles in both of crop production and livestocks. Legume-cereal intercropping in sustainable agricultural cropping system is the most applied in the intercropping systems in the World. Legume-cereal intercropping have many benefits such soil conservation, weed control, animal feed and effective land use, greater yield and quality

Received : 29/05/2021 Accepted : 08/07/2021 in low-input agricultural system. Land use efficiently is available to evaluate the advantages of intercrop in sustainable agriculture to meet food demand due to increase in population. Amount of $\mathrm{N}_{2}$ fixed by intercropped legume is less compared to mono crop legume due to competition with cereal. However, proportion of total $\mathrm{N}$ derived from fixation (Ndfa \%) in legume intercropped with cereal was greater than mono crop legume. $\mathrm{N}$-transfer from the legume to neighbouring plant may be possible, but it can be affected by a lot of factors. The principal aim of present study is to define

Keywords: advantages of cereal-grain legume intercrops in sustainable agriculture.

Grain legume-cereal intercropping

Sustainable agriculture

Environmental resource use Efficient $\mathrm{N}$ utilization Cropping system

\section{Introduction}

World faces inreasing human population, also it brings with some problems such as starvation and food security. At the present time, agriculture encounter some problems such as lack of food, soil erosion, excessive use of fertilizers and pesticide, food security (Jackson and Piper, 1989; Bedoussac and Justes, 2011; Raberg et al., 2017). For this reason, crop diversity and crop rotation play important role in agricultural systems. (Hauggaard-Nielsen et al., 2008). Future agriculture needs to demand organic crop without externeous resources. Sustainable agriculture may be part of the solution because it decreases use of synthetic nitrogen $(\mathrm{N})$ fertilizers and it can contribute to soil fertility by use crop rotation. Reganold and Wachter (2016) found that in organic production yield averages are 8 to $25 \%$ lower compared with traditional agriculture by using different data in meta-analyses. However, input cost in organic farming is less than in traditional farming (Lampkin and Padel, 1994). Organic farming encompasses sustanability and traditional crop rotation. This what every individual needs to know about benefit natural sciences, because almost all continent exposes global climate change. Due to these rising concern about exploit natural resources and environment pollution, sustainable agriculture its importance is understood. Sustainable agriculture provides food security to generation by means of eco-founctional practice. Intercropping has an important role in sustainable cropping systems. Legume-cereal intercrops are the most applied in the intercropping systems in the World. Legume-cereal intercrops have many benefits such soil conservation, weed control, animal feed and effective land use, greater yield and quality in lowinput agricultural systems. Intercropping is considerable for increased yield, decreased pest and reduced fertilizer $\mathrm{N}$ using (Jensen, 1996a; Jensen et al., 2020).

Intercropping is described as agronomic practice of growing the of two or more species together in the same area and time (Andrews and Kassam, 1976; Ofori and Stern, 1987). Mixed cropping of legumes and cereal is common (Ofori and Stern, 1987; Van Kessel and Hartley, 2000; Jensen et al., 2020) because legumes take place in crop rotation and they can be advantageous following crop. Legumes are fixing nitrogen in the roots by rhizobum. So, $\mathrm{N}$ transfer from the legume to non-legume may be affected by a lot of factors and it is very difficult (Jensen, 1996b). 
Further legumes contribute to soil improvement, human nutrition and improve of quality forage. However, there are affect many factors of mix crop for example; sowing time of crop, sowing rate, root structure, competitive, interactions between the component species, harvesting time of crop. Designing crop management systems based on crop ability compete with weed, legume to cereal ratio, resource use sharing, root arhitecture allellochemicals (Brisson et al., 2004). Yield of mix crop is advantage than sole crop. Intercropping is an insurance of yields. Besides it increases cereal grain protein content compared to mono crops. Some researchers reported that protein concentration of cereal grain and shoot in legume-cereal intercropping is higher than that of sole crop cereal. (Lithourgidis et al., 2007; Lauk and Lauk, 2008; Jensen et al., 2015). Cereal in intercropping is more competitive for inorganic $\mathrm{N}$ than pea (HauggaardNielsen et al., 2008). This reason may be growth root cereals has faster than legumes (Ghaley et al., 2005).

Intercropping boost land equivalent ratio, so in terms of LER intercropping is useful to natural resources as compared to respective sole crops (Yu et al., 2015). The aim of sustainable agriculture was to use efficiently resources for future generation and ecology. Farmers prefer lower input by using especially cereal /legume intercropping. Efficiency of intercrops are available for low nitrogen input farming systems (Willey, 1990; Fukai and Trenbath, 1993; Hauggaard-Nielsen, 2003; David et al., 2005; Desclaux et al., 2008; Bedoussac et al., 2015). In fact, that, protection of natural resources or biodiversity know remarkably important. Legumes take part in sustainability agriculture for major nitrojen source through symbiotic nitrogen fixation. It reduces environmental influence while ensuring sustainability of productivity in modern agriculture (Bedoussac et al., 2015).

The principal aim of this present study was revealed of cereal-grain legume intercrops relationship sustainable agriculture explaining that low input, eco-functional implement, nitrogen use, land equivalent ratio and economic output.

\section{Grain Production Potential of Intercropping}

Environmental resources are generally better used by intercrops than sole crop (Neugschwandtner and Kaul, 2014). It can be said that in terms of yield use plant growth factors better by intercrop than the sole crop. Similar observations were informed by some researchers for various systems (Jensen, 1996a; Hauggaard-Nielsen et al., 2008; Bedoussac et al., 2015). There are many factors affected productivity of mix crops such as sowing time of crop, sowing rate, root structure, competitive, interactions between the component species, harvesting time of crop. Competetive abilities of component crops change nonlegume and legume root structure. Grain yield of legumecereal intercrops obtained from various studies were shown in Table 1. Some studies reported that grain yield of sole crop legumes was lower than total grain yield in the intercrops (Haugaard Nielsen et al., 2001; Corre-Hellou et al., 2006; Knudsen et al., 2004; Sarunaite et al., 2010). However, total grain yield in oat-pea intercrops were generally less than in the sole crops (Arlauskiene et al., 2011). Grain yield of pure pea and pure wheat is significantly higher than intercropped components crop without $\mathrm{N}$ conditions (Ghaley et al., 2005).

Table 1. Grain yield potential of legume-ceral intercrops and sole crops in different studies.

\begin{tabular}{|c|c|c|c|}
\hline Country & Sole Crop Legume & Sole Crop Cereal & Legume-Cereal Intercrops \\
\hline${ }^{1}$ Denmark & pea $2630 \mathrm{~kg} \mathrm{ha}^{-1}$ & barley $3927 \mathrm{~kg} \mathrm{ha}^{-1}$ & $4577 \mathrm{~kg} \mathrm{ha}^{-1}$ \\
\hline${ }^{2}$ Denmark & $\begin{array}{c}\text { pea 388-394 } \mathrm{g} \mathrm{m}^{-2} \\
\text { (with N40 and with N5) }\end{array}$ & $\begin{array}{l}\text { barley 210-287 } \mathrm{g} \mathrm{m}^{-2} \\
\text { (with N5 and with N40) }\end{array}$ & $\begin{array}{c}307 \mathrm{~g} \mathrm{~m}^{-2} \\
\text { (in both cases) }\end{array}$ \\
\hline${ }^{3}$ Denmark & $\begin{array}{l}\text { pea } 268-490 \mathrm{~g} \mathrm{~m}^{-2} \\
\text { faba bean } 132-347 \mathrm{~g} \mathrm{~m}^{-2} \\
\text { lupin } 269-416 \mathrm{~g} \mathrm{~m}^{-2}\end{array}$ & $\begin{array}{l}\text { barley 211-339 } \mathrm{g} \mathrm{m}^{-2} \\
\quad \text { (sand soil and } \\
\text { sandy loam conditions) }\end{array}$ & $\begin{array}{l}231-455 \mathrm{~g} \mathrm{~m}^{-2} \\
207-394 \mathrm{~g} \mathrm{~m}^{-2} \\
220-337 \mathrm{~g} \mathrm{~m}^{-2}\end{array}$ \\
\hline${ }^{4}$ Denmark & $\begin{array}{c}\text { pea 378-395 } \mathrm{g} \mathrm{m}^{-2} \\
\text { (with } \mathrm{N} 4 \text { and without } \mathrm{N} \text { ) }\end{array}$ & $\begin{array}{c}\text { wheat } 127-478 \mathrm{~g} \mathrm{~m}^{-2} \\
\text { (without } \mathrm{N} \text { and with } \mathrm{N} 8 \text { ) }\end{array}$ & $\begin{array}{c}332-392 \mathrm{~g} \mathrm{~m}^{-2} \\
\text { (with N4 and with N8) }\end{array}$ \\
\hline${ }^{5}$ France & pea $491 \mathrm{~g} \mathrm{~m}^{-2}$ & barley $435 \mathrm{~g} \mathrm{~m}^{-2}$ & $563 \mathrm{~g} \mathrm{~m}^{-2}$ \\
\hline${ }^{6}$ Lithuania & \begin{tabular}{c|c}
$\begin{array}{c}\text { pea } \\
\text { lupin }\end{array}$ & $2368 \mathrm{~kg} \mathrm{ha}^{-1}$ \\
bean & $1507 \mathrm{~kg} \mathrm{ha}^{-1}$ \\
vetch & $1985 \mathrm{~kg} \mathrm{ha}^{-1}$ \\
(as mean of three years)
\end{tabular} & $\begin{array}{l}\text { wheat } 3146 \mathrm{~kg} \mathrm{ha}^{-1} \\
\text { (as mean of three years) }\end{array}$ & $\begin{array}{c}2930 \mathrm{~kg} \mathrm{ha}^{-1} \\
2774 \mathrm{~kg} \mathrm{ha}^{-1} \\
2836 \mathrm{~kg} \mathrm{ha}^{-1} \\
3338 \mathrm{~kg} \mathrm{ha}^{-1}\end{array}$ \\
\hline${ }^{7}$ Lithuania & pea $2936 \mathrm{~kg} \mathrm{ha}^{-1}$ & \begin{tabular}{c|l} 
wheat & $3002 \mathrm{~kg} \mathrm{ha}^{-1}$ \\
barley & $2583 \mathrm{~kg} \mathrm{ha}^{-1}$ \\
oat & $2897 \mathrm{~kg} \mathrm{ha}^{-1}$ \\
tritikale & $2717 \mathrm{~kg} \mathrm{ha}^{-1}$
\end{tabular} & $\begin{array}{l}2951 \mathrm{~kg} \mathrm{ha}^{-1} \\
2750 \mathrm{~kg} \mathrm{ha}^{-1} \\
2555 \mathrm{~kg} \mathrm{ha}^{-1} \\
2735 \mathrm{~kg} \mathrm{ha}^{-1}\end{array}$ \\
\hline${ }^{8}$ China & $\begin{array}{l}\text { pea } 2828 \mathrm{~kg} \mathrm{ha}^{-1} \\
\text { (as mean of three years) }\end{array}$ & $\begin{array}{c}\text { maize } 11724 \mathrm{~kg} \mathrm{ha}^{-1} \\
\text { (as mean of three years) }\end{array}$ & $\begin{array}{l}10331 \mathrm{~kg} \mathrm{ha}^{-1} \\
\text { (as mean of three years) }\end{array}$ \\
\hline${ }^{9}$ Lithuania & $\begin{array}{c}\text { pea } 2795-3127 \mathrm{~kg} \mathrm{ha}^{-1} \\
\quad(\text { two location) } \\
\text { (as mean of three years) }\end{array}$ & $\begin{array}{l}\text { wheat } 2856-3740 \mathrm{~kg} \mathrm{ha}^{-1} \\
\text { triticale } 2726-3152 \mathrm{~kg} \mathrm{ha}^{-1} \\
\text { oat } 3043-3226 \mathrm{~kg} \mathrm{ha}^{-1} \\
\text { barley } 2779-3594 \mathrm{~kg} \mathrm{ha}^{-1} \\
\text { (as mean of three years) }\end{array}$ & $\begin{array}{c}3044-3084 \mathrm{~kg} \mathrm{ha}^{-1} \\
2853-3432 \mathrm{~kg} \mathrm{ha}^{-1} \\
2740-3484 \mathrm{~kg} \mathrm{ha}^{-1} \\
2939-3356 \mathrm{~kg} \mathrm{ha}^{-1} \\
\text { (as mean of three years) }\end{array}$ \\
\hline
\end{tabular}

Sources:1: Haugaard Nielsen et.al., 2001; 2: Andersen et al., 2004; 3: Knudsen et al. 2004; 4: Ghaley et al., 2005; 5: Corre -Hellou et al. 2006; 6: Sarunaite et al., 2010; 7: Arlauskiene et al., 2011; 8: Qin et al., 2013; 9: Arlauskiene et al., 2014 
Table 2. Effect of different planting pattern on bean and wheat grain in intercropping

\begin{tabular}{l|llllllll}
\hline Cropping system & B Sole & W Sole & B M1 & W M1 & B M2 & W M2 & B M3 & W M3 \\
\hline Grain yield (t/ha) & 4.85 & 2.33 & 4.23 & 1.01 & 4.13 & 1.98 & 4.21 & 1.11 \\
HarvestIndex (\%) & 34.30 & 30.87 & 41.02 & 24.9 & 41.57 & 24.25 & 43.22 & 25.5 \\
1000- Grain Weight (g) & 398.7 & 39.2 & 426.85 & 35.57 & 431.75 & 36.22 & 435.15 & 37.3 \\
\hline
\end{tabular}

M1: alternate row intercrop; M2: within row intercrop; M3: mixed intercrop B: Bean W: Wheat. Sources: Eskandri and Ghanbari, 2010

Table 3. Land equivalent ratios for grain in the various intercropping in the some studies.

\begin{tabular}{l|ccc}
\hline \multicolumn{1}{c|}{ Country } & Intercropping & Application & LER \\
\hline${ }^{1}$ England & pea-oat & different N application & $0.85-0.91$ \\
${ }^{2}$ Nigeria & cowpea-pearl millet & different periods & $1.08-1.43$ \\
${ }^{3}$ Yugoslavia & maize-bean & irrigation and rainy conditions & $0.93-1.11$ \\
${ }^{4}$ Denmark & pea- barley & without N and & $1.03-1.18$ \\
${ }^{5}$ Ethiopia & bean- maize & with 40-50 kg N ha & $0.76-1.41$ \\
${ }^{6}$ Ethiopia & faba bean-barley & different N-P applications & $1.05-1.21$ \\
${ }^{7}$ Poland & pea-barley & different mixture rates & $1.18-2.01$ \\
${ }^{8}$ China & pea- maize-wheat & different cultivars & $1.20-1.50$ \\
${ }^{9}$ Czech Republic & pea-cereal & different components & $1.04-1.26$ \\
${ }^{10}$ Austria & pea-oat & different mixture rates & $0.79-0.98$ \\
\hline Sources: $1:$ Cowell et al. $1989 ; 2:$ Reddy et al., 1992; 3. Oljaca et al. 2000; 4: Hauggard- Nielsen and Jensen, 2001; 5: Abera et al., 2005; 6: Agegnehu
\end{tabular}
et al., 2006; 7: Podgorska- Lesiak and Sobkowicz, 2013; 8: Qin et al., 2013; 9. Hunady and Hochman 2014; 10: Neugschwandther and Kaul, 2014.

The planting systems are one of the most important agronomic applications. Maize with soybean at $10 \mathrm{~cm}$ intra spacing increased grain yield (Berdjour et al., 2020). Great soybean yield was provided without affecting maize yield in strip intercropping systems (Du et al., 2018). On the other hand, Eskandri and Ghanbari (2010) indicated that differences among the intercrop planting system were no significant for seed yield of bean and wheat in the intecropping, but grain yield increased in sole crops as compared with intercropped components crops (Table 2).

\section{Role of Intercropping in Weed, Pest and Disease Control}

Intercrop yield stabilite depend on weed density, location, ecolological conditions and disease and pest. Weed pressure in legume and cereal intercrops was less than sole crop legume (Hauggaard-Nielsen et al., 2008; Corre-Hellou et al., 2011; Bedoussac et al., 2015). Corre-Hellou et al. (2011) reported that sole crop cereal and intercrop three times advantage compared to pure legume. This reason for this situation intercrop may press weed thanks to alleopathy. Therefore, it might not be suitable organic agriculture, due to excess of weed population sole crop, other benefits of intercrops are lower weed biomass and pest and disease population. Spring sole pea has weed dry matter more than pea- barley intercrop or pea-wheat intercrop or sole barley and sole wheat by Naudin et al. (2009). One of the reasons in intercrop is host plant density. Banik et al. (2006) reported that weed biomass in chickpea-wheat intercrop $(20 \mathrm{~cm}$ spacing) is lower than about $45 \%$ sole crop wheat $(20 \mathrm{~cm}$ spacing). Components of intercropping can be affected less by pest and disease than mono crops. Intercrops may usefully contribute to the control of pest or disease populations and the decreasing yield loss (Trenbath, 1993).

Legumes (pea, faba bean, lupin)-barley intercrops observed that reduced severity disease by $20 \%$ to $40 \%$ (Hauggard-Nielsen et al., 2009).

\section{Effective Utilization of Environmental Resources}

Yield of intercropping are due to effectively utilization of environmental resources. Substainable agriculture in land use efficiently may be acquire by using mixtures, especially legume/cereal mixtures. Land equivalent ratio (LER) indicates efficiency of intercrops for using the planth growth sources compared with sole crops. Efficient utilization of plant growth factors is useful to evaluate the advantages of intercrop in sustainable agriculture to meet food demand due to increase in population. That is if LER $>1$ is defined as intercropping more effective for light, water and nitrogen than sole crops (Corre-Hellou et al., 2009; Liu et al., 2018). Hauggaard-Nielsen et al. (2006) found that in both harvest stage land equivalent ratios (LER) values of the intercrops ranged from 1.08 to 1.21. Some researchers showed that various intercrops utilise plant growth factors more effectively $\% 25-50$ as compared to sole crop (Hauggaard-Nielsen et al., 2001; HauggaardNielsen et al., 2008). Highest LER was found in maize+soybean double row strips (Üstündağ and Ünay, 2016). Land equivalent ratios for grain in the various intercropping in some studies are exhibited in Table 3. Pea and barley intercropping under low $\mathrm{N}$ fertilization condition also used more efficiently environmental sources for plant growth than sole crop (Jensen, 1996a). When applied $\mathrm{N}$ fertilization $\mathrm{LER}<1$ for grain was found in peaoat intercropping (Cowell et al. 1989; Neugschwandther and Kaul, 2014).

\section{Improvement of Forage Yield and Quality}

One of the main principles of sustainable agriculture is rising self-sufficiency. Especially livestock farmers may be interested in this principle (Hunady and Hochman, 2014). Actually, sustainable agriculture systems stand out some subject such as ecology, self-sufficiency, economy. In animal nutrition, legume /cereal mixtures provide balance nutrition as well as higher biomass production. Many farmers grow only cereal forage because of low cost. All the same legumes contain protein and fiber for animal husbandry therefore feeding on sole crop cereal is not suitable forage quality (Eskandari et al., 2009). Legumecereal intercropping give high forage yield and quality for livestocks. Crude protein content and total forage dry matter digestibility of maize and cowpea intercrops increased as 
compared to mono crops (Dahmardeh et al., 2009). Dry matter yield and quality silage fodder of corn-legumes intercrops were higher than pure stand corn (Geren et al., 2008; Eskandari, 2012). Lithourgidis et al. (2007) reported that common barley-vetch (35-65) intercrops produced higher forage yield and quality than pure vetch crops and other intercrops. On the other hand, sorghum-sudangrass hybrid and legume intercrops gave more hay and protein yield as compared with sole crops (Başaran et al., 2017).

\section{Soil Fertility and Conservation}

Legumes and cereal intercrops are considerable for soil conservation and it can be used as cover crop. $\mathrm{N}$ is mobilize element, so cover crop can restriction $\mathrm{N}$ leaching especially rainy areas. Frasier et al. (2017) found that grass-legume intercrop can restrain $\mathrm{N}$ losses and the mixture more efficient in terms of nitrojen use. Sorghum-cowpea intercropping decreased soil loss compared to sole crops (Zougmore et al., 2000). Shallow roots help to reduce soil erosion and intercrops prevent soil loss in the regions with excessive rainfall (Lithourgidis et al., 2011; Dwivedi et al., 2015).

Inorganic nitrogen fertilizer causes environmental damage, so biological nitrogen fixation in legumes is important for sustainable agriculture. Legumes in the intercropping can decompose and benefit subsequent crops (Lithourgidis et al., 2011). Usually, most legumes gather $\mathrm{N}$ from biological fixation especially in days to $50 \%$ flowering time and days to $100 \%$ flowering time. Biological $\mathrm{N}$ fixation is substantial source in legume-cereal intercrops in limited nitrogen conditions (Fujita et al., 1992). Legume-maize intercropping improves production and the soil fertility characters for at least three to four years especially at favourable phosphours fertilization (Wang et al., 2014). Mung bean and rice intercropping increases nodulation, nitrogen and phousphorus acquisition in legumes by mycorrhiza formation ( $\mathrm{Li}$ et al., 2009). Inoculation with mycorrhiza increased transfered $\mathrm{N}$ from legume in faba bean- wheat and mung bean-rice intercrops (Li et al., 2009; Ingraffia et al., 2019). Intercrops can increase not only organic $\mathrm{C}$ content in soil, but also microbial activity can maintain. Depending on soil $\mathrm{C}: \mathrm{N}$ ratio and root structure of crops, soil organic decomposes of soil organic matter monocrop slower than intercrop (Cong et al., 2015).

\section{Efficient $N$ Utilization}

Symbiotic $\mathrm{N}_{2}$ fixation is very important for sustainable agricultural systems. Legumes are biological source of nitrogen throughout rhizobium bacteria. Amount of nitrogen fixed by the legumes in legume-cereal intercrops is related to species, density of component crops, root ability and competitive abilities of components (Ofori and Stern, 1987). Nitrogen fixation related on total $\mathrm{N}$ acquiremet and proportion of $\mathrm{N}$ derived from air or $\%$ Ndfa. Although legume is known to be are great resource of nitrojen, many farmers to continue inorganic fertilizers use because of their habit. Ndfa \% of legume-cereal intercrops and sole crops in some the studies was exhibited in Table 4. Ndfa \% in monocropped legumes had lower than intercropped legumes however it is depending on area, crop diversity (Jensen, 1996a; Corre-Hellou et al., 2006; Andersen et al., 2004; Haugaard Nielsen et al., 2009; Chu et al., 2004). However, Ndfa \% in peanut- rice and peabarley intercrops reduce with increasing inorganic $\mathrm{N}$ in soil (Andersen et al., 2004; Chu et al., 2004). Amount of $\mathrm{N}_{2}$ fixed intercropped pea is less than sole crop pea due to competition with wheat (Hauggaard-Nielsen et al., 2001). However, proportion of total $\mathrm{N}$ derived from fixation (Ndfa $\%$ ) in pea intercropped with cereal was greater than in sole cropped pea without $\mathrm{N}$ fertilizer (Ghaley et al., 2005; Hauggaard-Nielsen et al., 2009). On the other hand, there was no significant difference between relative amount of $\mathrm{N}_{2}$ fixed by pea in intercropping pea with barley or sole cropped pea at the low nitrogen level (Andersen et al., 2005). Fan et al. (2006) reported that Ndfa \% increase in wheat-faba bean intercropping compared to maize- faba bean without nitrogen fertilization condition. Plant density affects nitrogen acquisition in intercropping. High biomass and grain nitrogen content of intercropped barley were obtained in higher pea density (Chapagain and Riseman, 2014).

The competition of the cereal is greater than of the legume for uptake of soil $\mathrm{N}$ in intercropping (Jensen, 1996a; Ghaley et al., 2005; Dwivedi et al., 2015). In fact, $\mathrm{N}$ percentage in grain of intercropped barley was more than mono crop barley (Hauggaard-Nielsen et al., 2001). The highest grain $\mathrm{N}$ yield was accumulated in $\mathrm{N}_{0}$ for sole cropped pea followed by the intercops (Ghaley et al., 2005).

Table 4. Ndfa \% in various intercrops and sole crops in some the studies.

\begin{tabular}{|c|c|c|c|c|}
\hline Country & Intercrops & Fertilizer & Sole Crop Ndfa \% & Intercrop Ndfa \% \\
\hline \multirow{3}{*}{${ }^{1} \mathrm{USA}$} & \multirow{3}{*}{$\begin{array}{c}\text { Cowpea } \\
\text { maize }\end{array}$} & \multicolumn{3}{|c|}{50 DAP $\left(\mathrm{kg} \mathrm{ha}^{-1}\right) 23.6-41.4 \mathrm{dd}$. of rows $47.9-51.7 \mathrm{dd}$. of rows } \\
\hline & & 80 DAP $\left(\mathrm{kg} \mathrm{ha}^{-1}\right)$ & $5.8-30.6$ & $34.4-44.2$ \\
\hline & & & dd. of rows & dd. of rows \\
\hline${ }^{2}$ Denmark & pea- barley & $50 \mathrm{~kg} \mathrm{~N} \mathrm{ha}^{-1}$ & $45.0-62.0 \mathrm{dp}$. & $73.0-82.0 \mathrm{dp}$ \\
\hline \multirow{2}{*}{${ }^{3}$ Denmark } & \multirow{2}{*}{ pea-barley } & $0.5 \mathrm{~g} \mathrm{~N} \mathrm{~m}^{-2}$ & $58.0-79.0 \mathrm{dp}$. & $81.0-87.0 \mathrm{dp}$. \\
\hline & & $4 \mathrm{~g} \mathrm{~N} \mathrm{~m}^{-2}$ & $61.0-88.0 \mathrm{dp}$. & $76.0-85.0 \mathrm{dp}$. \\
\hline \multirow{3}{*}{${ }^{4}$ China } & \multirow{3}{*}{ peanut-rice } & $15 \mathrm{~kg} \mathrm{~N} \mathrm{ha}^{-1}$ & 72.8 & 76.1 \\
\hline & & $75 \mathrm{~kg} \mathrm{~N} \mathrm{ha}^{-1}$ & 56.5 & 53.3 \\
\hline & & $150 \mathrm{~kg} \mathrm{~N} \mathrm{ha}^{-1}$ & 35.4 & 50.7 \\
\hline${ }^{5}$ France & pea -barley & $0-30-130 \mathrm{~kg} \mathrm{~N} \mathrm{ha}^{-1}$ & 64.6 & 75.9 \\
\hline${ }^{6}$ Denmark, United Kingdom, France, Germa & pea- barley & Organic cropp & ing system 66.4 & 72.9-73.4 dmr. \\
\hline
\end{tabular}

Sources: 1: Van Kessel and Roskoski, 1988; 2: Jensen 1996a; 3: Andersen et al., 2004; 4: Chu et al., 2004; 5: Corre-Hellou et al. 2006; 6: Haugaard

Nielsen et.al., 2009. dd: different distances, dp: different period, dmr: different mixture rate 
Intercrops show that grain protein concentration of cereal increase compared with sole crop (Pelzer et al., 2016). Grain $\mathrm{N}$ contentration in cereal combined with legume higher than sole cereal but it is depending on cultivar and soil conditions. Hauggaard-Nielsen et al. (2008) showed that grain $\mathrm{N}$ concentration of sole crop barley is $1.43 \%$ in sandy soil while grain $\mathrm{N}$ concentration of barley-pea intercrop is $1.80 \%$ in sandy loam soil. Protein content $(11.1 \%)$ in grain of intercropped cereal was higher as compared with cereal monocrop $(9.8 \%)$, but difference between intercropped legume and sole cropped legume is not significant for protein content in grain (Bedoussac et al., 2015). Similarly, Neumann et al. (2007) reported that nitrogen conceration in grain of intercropped pea and oat in the intercropping as compared with sole crops in both of conventional and minumum tillage systems.

$\mathrm{N}$-transfer from the legume to non-legume plant may be possibble, but it can be affected by a lot of factors and it is very difficult (Jensen, 1996b). Therefore, amount of transferred $\mathrm{N}$ to non-legume may be smaller in cereal than amount of $\mathrm{N}$ taken up from other resources (Jensen, 1996a).

\section{Conclusions}

Sustainable agriculture provides food security to generation by means of eco-founctional practice. Intercropping has an important role in sustainable cropping systems. Legume-cereal intercrops are the most applied in to the intercropping systems in the World and it has many benefits such soil conservation, improvement of soil fertility, weed control, animal feed and efective land use, greater yield and quality in low-input agricultural system. Legume-cereal intercropping for great biomass and grain production must be grown in low-input agriculture. Yield of intercropping are due to effectively utilization of environmental resources. $\mathrm{N}$ content in grain of intercropped cereal increases compared to sole crop. Legume and cereal intercropping under low $\mathrm{N}$ fertilization condition also used more efficiently for plant growth sources such as for light, water and nitrogen.

\section{References}

Abera T, Feyissa D, Yusuf H. 2005. Effects of inorganic and organic fertilizers on grain yield of maize-climbing bean intercropping and soil fertility in Western Oromiya, Ethiopia. Conference on International Agricultural research for development. Stuttgart-Hohenheim. 11-13 October, 2005.

Agegnehu G, Ghizaw A, Sinebo W. 2006. Yield performance and land-use efficiency of barley and faba bean mixed cropping in Ethiopian highlands. European Journal of Agronomy, 25(3): 202-207.

Andersen MK, Hauggaard-Nielsen H, Ambus P, Jensen ES. 2004. Biomass production, symbiotic nitrogen fixation and inorganic $\mathrm{N}$ use in dual and tri-component annual intercrops. Plant and Soil, 266(1): 273-287.

Andrews D, Kassam A. 1976. The importance of multiple cropping in increasing world food supplies. Multiple Cropping, 27: 1-10.

Arlauskienė A, Maikštėnienė S, Šarūnaitė L, Kadžiulienè Ž, Deveikytė I, Žèkaitė V, Česnulevičienè R. 2011. Competitiveness and productivity of organically grown pea and spring cereal intercrops, Žemdirbystè = Agriculture. 98(4): 339

Arlauskienė A, Šarūnaitė L, Kadžiulienė Ž, Deveikytė I, Maikštėnienè S. 2014. Suppression of annual weeds in pea and cereal intercrops. Agronomy Journal. 106(5): 1765-1774.
Banik P, Midya A, Sarkar B, Ghose S. 2006. Wheat and chickpea intercropping systems in an additive series experiment: advantages and weed smothering. European Journal of agronomy, 24(4): 325-332.

Basaran U, Dogrusoz MC, Gulumser E, Hanife M. 2017. Hay yield and quality of intercropped sorghum-sudan grass hybrid and legumes with different seed ratio. Turkish Journal of Field Crops, 22(1): 47-53.

Bedoussac L, Justes E. 2011. A comparison of commonly used indices for evaluating species interactions and intercrop efficiency: application to durum wheat-winter pea intercrops. Field Crops Research, 124(1): 25-36.

Bedoussac L, Journet EP, Hauggaard-Nielsen H, Naudin C, Corre-Hellou G, Jensen ES, Prieur L, Justes E. 2015. Ecological principles underlying the increase of productivity achieved by cereal-grain legume intercrops in organic farming. a review. Agronomy for Sustainable Development, 35(3): 911-935.

Berdjour A, Dugje IY, Dzomeku IK, Rahman NA. 2020. Maizesoybean intercropping effect on yield productivity, weed control and diversity in northern Ghana. Weed Biology and Management, 20: 69-81.

Chapagain T, Riseman A. 2014. Barley-pea intercropping: effects on land productivity, carbon and nitrogen transformations. Field Crops Research, 166: 18-25.

Chu GX, Shen QR, Cao J. 2004. Nitrogen fixation and N transfer from peanut to rice cultivated in aerobic soil in an intercropping system and its effect on soil $\mathrm{N}$ fertility. Plant and Soil, 263(1): 17-27.

Cong WF, Hoffland E, Li L, Janssen BH, Van Der Werf W. 2015. Intercropping affects the rate of decomposition of soil organic matter and root litter. Plant and Soil, 391(1): 399-411.

Corre-Hellou G, Fustec J, Crozat Y. 2006. Interspecific competition for soil $\mathrm{N}$ and its interaction with $\mathrm{N}_{2}$ fixation, leaf expansion and crop growth in pea-barley intercrops. Plant and Soil, 282(1): 195-208.

Corre-Hellou G, Faure M, Launay M, Brisson N, Crozat Y. 2009. Adaptation of the STICS intercrop model to simulate crop growth and $\mathrm{N}$ accumulation in pea-barley intercrops. Field Crops Research, 113: 72-81. doi:10.1016/j.fcr.2009.04.007

Corre-Hellou G, Dibet A, Hauggaard-Nielsen H, Crozat Y, Gooding M, Ambus P, Dahlmann C, von Fragstein P, Pristeri A, Monti M. 2011. The competitive ability of pea-barley intercrops against weeds and the interactions with crop productivity and soil $\mathrm{N}$ availability. Field Crops Research, 122(3): 264-272.

Cowell L, Bremer E, Kessel CV. 1989. Yield and $\mathrm{N}_{2}$ fixation of pea and lentil as affected by intercropping and $\mathrm{N}$ application. Canadian Journal of Soil Science, 69(2): 243-251.

Dahmardeh M, Ghanbari A, Syasar B, Ramroudi M. 2009. Effect of intercropping Maize (Zea mays L.) with cowpea (Vigna unguiculata L.) on green forage yield and quality evaluation. Asian Journal of Plant Sciences, 8(3): 235-239.

David C, Jeuffroy MH, Henning J, Meynard JM. 2005. Yield variation in organic winter wheat: a diagnostic study in the Southeast of France. Agronomy Sustainable for Development, 25: 213-223.

Desclaux D, Nolot JM, Chiffoleau Y, Gozé E, Leclerc C. 2008. Changes in the concept of genotype $\times$ environment interactions to fit agriculture diversification and decentralized participatory plant breeding: pluridisciplinary point of view. Euphytica, 163(3): 533.

Du J, Han T, Gai J, Yong T, Sun X, Wang X, Yang F, Liu J, Shu K, Liu W, Yang W. 2018. Maize-soybean strip intercropping: Achieved a balance between high productivity and sustainability. Journal of Integrative Agriculture, 17(4): 747-754.

Dwivedi A, Dev I, Kumar V, Yadav RS, Yadav M, Gupta D, Singh A, Tomar S. 2015. Potential role of maize-legume intercropping systems to improve soil fertility status under smallholder farming systems for sustainable agriculture in India. International Journal of Life Sciences Biotechnology and Pharma Research, 4(3): 145. 
Eskandari H, Ghanbari A, Javanmard A. 2009. Intercropping of cereals and legumes for forage production. Notulae Scientia Biologicae, 1(1): 07-13.

Eskandari H, Ghanbari A. 2010. Effect of different planting pattern of wheat (Triticum aestivum) and bean (Vicia faba) on grain yield, dry matter production and weed biomass. Notulae Scientia Biologicae, 2(4): 111-115.

Eskandari H. 2012. Yield and quality of forage produced in intercropping of maize (Zea mays) with cowpea (Vigna sinensis) and mungbean (Vigna radiate) as double cropped. Journal of Basic and Applied Scientific Research, 2(1): 9397.

Fan F, Zhang F, Song Y, Sun J, Bao X, Guo T, Li L. 2006. Nitrogen fixation of faba bean (Vicia faba L.) interacting with a non-legume in two contrasting intercropping systems. Plant and Soil, 283(1): 275-286.

Frasier I, Noellemeyer E, Amiotti N, Quiroga A. 2017. Vetch-rye biculture is a sustainable alternative for enhanced nitrogen availability and low leaching losses in a no-till cover crop system. Field Crops Research, 214: 104-112.

Fujita K, Ofosu-Budu K, Ogata S. 1992. Biological nitrogen fixation in mixed legume-cereal cropping systems. Plant and Soil, 141(1): 155-175.

Fukai S, Trenbath B. 1993. Processes determining intercrop productivity and yields of component crops. Field Crops Research, 34(3-4): 247-271.

Geren H, Avcioglu R, Soya H, Kir B. 2008. Intercropping of corn with cowpea and bean: Biomass yield and silage quality. African Journal of Biotechnology, 7(22):4100-4104

Ghaley BB, Hauggaard-Nielsen H, Høgh-Jensen H, Jensen ES. 2005. Intercropping of wheat and pea as influenced by nitrogen fertilization. Nutrient Cycling in Agroecosystems, 73(2): 201-212.

Hauggaard-Nielsen H, Jensen ES. 2001. Evaluating pea and barley cultivars for complementarity in intercropping at different levels of soil $\mathrm{N}$ availability. Field Crops Research, 72(3): 185-196.

Hauggaard-Nielsen H, Ambus P, Jensen ES. 2001. Interspecific competition, $\mathrm{N}$ use and interference with weeds in pea-barley intercropping. Field Crops Research, 70(2): 101-109.

Hauggaard-Nielsen H, Ambus P, Jensen ES. 2003. The comparison of nitrogen use and leaching in sole cropped versus intercropped pea and barley. Nutrient Cycling in Agroecosystems, 65(3): 289-300.

Hauggaard-Nielsen H, Andersen MK, Jornsgaard B, Jensen ES. 2006. Density and relative frequency effects on competitive interactions and resource use in pea-barley intercrops. Field Crops Research. 95(2-3): 256-267. doi:10.1016/j.fcr. 2005.03.003

Hauggaard-Nielsen' H, Jornsgaard B, Kinane J, Jensen ES. 2008. Grain legume-cereal intercropping: The practical application of diversity, competition and facilitation in arable and organic cropping systems. Renewable Agriculture and Food Systems, 23(1): 3-12.

Hauggaard-Nielsen H, Gooding M, Ambus P, Corre-Hellou G, Crozat Y, Dahlmann C, Dibet A, Von Fragstein P, Pristeri A, Monti M. 2009. Pea-barley intercropping for efficient symbiotic $\mathrm{N}_{2}$-fixation, soil $\mathrm{N}$ acquisition and use of other nutrients in European organic cropping systems. Field Crops Research, 113(1): 64-71.

Hunady I, Hochman M. 2014. Potential of legume-cereal intercropping for increasing yields and yield stability for selfsufficiency with animal fodder in organic farming. Czech Journal of Genetics and Plant Breeding. 50(2): 185-194.

Ingraffia R, Amato G, Frenda AS, Giambalvo D. 2019. Impacts of arbuscular mycorrhizal fungi on nutrient uptake, $\mathrm{N}_{2}$ fixation, $\mathrm{N}$ transfer, and growth in a wheat/faba bean intercropping system. Plos One, 14(3): e0213672.

Jackson W, Piper J. 1989. The necessary marriage between ecology and agriculture. Ecology, 70(6): 1591-1593.
Jensen ES. 1996a. Grain yield, symbiotic $\mathrm{N}_{2}$ fixation and interspecific competition for inorganic nitrogen in pea+ barley intercrop. Plant and Soil, 182(1): 25-38.

Jensen ES. 1996b. Barley uptake of $\mathrm{N}$ deposited in the rhizosphere of associated field pea. Soil Biology and Biochemistry, 28(2): 159-168.

Jensen ES, Bedoussac L, Carlsson G, Journet EP, Justes E, Hauggaard-Nielsen H. 2015. Enhancing yields in organic crop production by eco-functional intensification. Sustainable Agricultural Research, 4(3): 42-50.

Jensen ES, Carlsson G, Hauggaard-Nielsen H. 2020. Intercropping of grain legumes and cereals improves the use of soil $\mathrm{N}$ resources and reduces the requirement for synthetic fertilizer N: A global-scale analysis. Agronomy for sustainable development, 40(1): 1-9.

Knudsen MT, Hauggaard-Nielsen H, Joernsgaard B, Jensen ES. 2004. Comparison of interspecific competition and $\mathrm{N}$ use in pea-barley, faba bean-barley and lupin-barley intercrops grown at two temperate locations. The Journal of Agricultural Science, 142: 617.

Lampkin NH, Padel S. 1994. Organic farming and agricultural policy in Western Europe: An overview. In: Lampkin, N.H., Padel, S. (editors.), The Economics of Organic Farming. CAB International, Oxon, UK, pp. 437-457.

Lauk R, Lauk E. 2008. Pea-oat intercrops are superior to peawheat and pea-barley intercrops. Acta Agriculturae Scandinavica Section B-Soil and Plant Science, 58(2): 139144.

Li Y, Ran W, Zhang R, Sun S, Xu G. 2009. Facilitated legume nodulation, phosphate uptake and nitrogen transfer by arbuscular inoculation in an upland rice and mung bean intercropping system. Plant and Soil, 315(1): 285-296.

Liu X, Rahman T, Song C, Yang F, Su B, Cui L, Bu W, Yang W. 2018. Relationships among light distribution, radiation use efficiency and land equivalent ratio in maize-soybean strip intercropping. Field Crops Research, 224: 91-101.

Lithourgidis A, Dhima K, Vasilakoglou I, Dordas C, Yiakoulaki M. 2007. Sustainable production of barley and wheat by intercropping common vetch. Agronomy for Sustainable Development, 27(2): 95-99.

Lithourgidis A, Dordas C, Damalas CA, Vlachostergios D. 2011. Annual intercrops: an alternative pathway for sustainable agriculture. Australian Journal of Crop Science, 5(4): 396-410.

Naudin C, Aveline A, Corre-Hellou G, Dibet A, Jeuffroy MH, Crozat Y. 2009. Agronomic analysis of the performance of spring and winter cereal-legume intercrops in organic farming. Journal of Agricultural Science and Technology, 3: 17-28.

Neumann A, Schmidtke K, Rauber R. 2007. Effects of crop density and tillage system on grain yield and $\mathrm{N}$ uptake from soil and atmosphere of sole and intercropped pea and oat. Field Crops Research, 100(2-3): 285-293.

Neugschwandtner RW, Kaul HP. 2014. Sowing ratio and N fertilization affect yield and yield components of oat and pea in intercrops. Field Crops Research, 155: 159-163.

Ofori F, Stern W. 1987. Cereal-legume intercropping systems. Advances in Agronomy, 41: 41-90.

Oljaca S, Cvetkovic R, Kovacevic D, Vasic G, Momirovic N. 2000. Effect of plant arrangement pattern and irrigation on efficiency of maize (Zea mays) and bean (Phaseolus vulgaris) intercropping system. The Journal of Agricultural Science, 135(3): 261-270.

Pelzer E, Bazot M, Guichard L, Jeuffroy MH. 2016. Crop management affects the performance of a winter pea-wheat intercrop. Agronomy Journal, 108(3): 1089-1100.

Podgórska-Lesiak M, Sobkowicz P. 2013. Prevention of pea lodging by intercropping barley with peas at different nitrogen fertilization levels. Field Crops Research, 149: 95-104.

Qin AZ, Huang GB, Chai Q, Yu AZ, Huang P. 2013. Grain yield and soil respiratory response to intercropping systems on arid land. Field Crops Research, 144: 1-10. 
Raberg TM, Carlsson G, Jensen ES. 2017. Productivity in an arable and stockless organic cropping system may be enhanced by strategic recycling of biomass. Renewable Agriculture and Food Systems, 34(1): 20-32

Reddy K, Visser P, Buckner P. 1992. Pearl millet and cowpea yields in sole and intercrop systems, and their after-effects on soil and crop productivity. Field Crops Research, 28(4): 315326.

Reganold JP, Wachter JM. 2016. Organic agriculture in the twenty-first century. Nature Plants, 2(2): 15221. doi:10.1038/nplants.2015.221

Šarūnaitė L, Deveikytė I, Kadžiulienè Ž. 2010. Intercropping spring wheat with grain legume for increased production in an organic crop rotation. Žemdirbyste $=$ Agric, 97: 51-58.

Trenbath B. 1993. Intercropping for the management of pests and diseases. Field Crops Research, 34(3-4): 381-405.

Üstündağ IY, Ünay A. 2016. Effect of maize/legume intercropping on crop productivity and soil compaction. Anadolu Journal of Agricultural Sciences, 31(2): 268-274.
Van Kessel C, Roskoski JP. 1988. Row spacing effects of N 2 fixation, $\mathrm{N}$-yield and soil $\mathrm{N}$ uptake of intercropped cowpea and maize. Plant and Soil, 111(1): 17-23.

Van Kessel C, Hartley C. 2000. Agricultural management of grain legumes: has it led to an increase in nitrogen fixation? Field Crops Research, 65(2-3): 165-181.

Wang ZG, Jin X, Bao XG, Li XF, Zhao JH, Sun JH, Christie P, $\mathrm{Li}$ L. 2014. Intercropping enhances productivity and maintains the most soil fertility properties relative to sole cropping. Plos One, 9: e113984.

Willey RW. 1990. Resource use in intercropping systems. Agricultural water management, 17(1-3): 215-231.

Yu Y, Stomph TJ, Makowski D, Van der Werf W. 2015. Temporal niche differentiation increases the land equivalent ratio of annual intercrops: a meta-analysis. Field Crops Research, 184: 133-144.

Zougmore R, Kambou F, Ouattara K, Guillobez S. 2000. Sorghum-cowpea intercropping: an effective technique against runoff and soil erosion in the Sahel (Saria, Burkina Faso). Arid Soil Research and Rehabilitation, 14(4): 329-342. 